\title{
Striga hermonthica (Del.) Benth has Dual Negative Effect on its Host Sorghum bicolor (L.) Moench
}

\begin{abstract}
Tigist Beyene ${ }^{1, a}$, Meseret Chimdessa Egigu ${ }^{2, b, *}$
${ }^{1}$ Department of Biology, Oda Bultum University, P.O. Box: 226, Chiro, Ethiopia

${ }^{2}$ School of Biological Sciences and Biotechnology, P.O. Box: 138, Dire Dawa, Ethiopia

*Corresponding author

\begin{tabular}{l|l}
\hline A R T I C L E I N F O & A B S T R A C T \\
\hline & Striga is a parasitic weed causing remarkable yield lose in Sorghum bicolor. In this study,
\end{tabular}

Research Article

Received : 16/08/2019

Accepted : 21/12/2019

phytotoxicity of leaf and flower extracts of Striga hermonthica were investigated on three sorghum varieties under laboratory conditions. Before allelopathic bioassay, total phenolics, alkaloids and terpenoids were quantified in the extracts. For allelopathic bioassay, 5 and 10\% (w/v) aqueous extracts were prepared by reconstituting dried crude extracts of leaf and flower of S. hermonthica in distilled water. Varieties of sorghum named Muyra 1 (M1), Muyra 2 (M2) and Fendishe (Fe) were treated with equal amounts of 5 and $10 \%(w / v)$ extracts in Petri dishes lined with Whatman no.1 filter paper. The control treatment received distilled water and treatments were laid out in a completely randomized design with three replications. Germination parameters were monitored for 15 days and General linear model was used to analyze data. Results showed that both leaf and flower of S. hermonthica produce phenolics, alkaloids and terpenoids. Values of total phenolics and total alkaloids did not show significant variation, whereas total terpenoid was significantly higher in flower than leaf. Percent germination, shoot and root lengths as well as their dry weights were significantly affected by extract concentration, sorghum variety and their interactions. Compared to control, percent germination and seedling growth were highly reduced at $5 \% \mathrm{w} / \mathrm{v}$ extract concentration and completely inhibited at $10 \% \mathrm{w} / \mathrm{v}$ extract concentration. Varieties were not differentially affected by leaf extracts, but M1 and M2 appeared to be more affected than Fe by flower extract. The result also showed that root growth was more affected by extracts than shoot growth. Overall, this study for the first time revealed that S. hermonthica reduces yield of S. bicolor not only due to parasitism, but also through its negative allelopathic effect on seed germination and early seedling growth.
\end{abstract}

\section{Introduction}

Striga hermonthica (Del.) Benth. (Orobanchaceae) is commonly known as purple witchweed as its English common name. Locally in Ethiopia, it is called by the name 'Akenchira'. Sorghum, (Sorghum bicolor L. Moench [Poaceae]) is one of the world's major cereal crops and the fifth most important crop globally after rice, wheat, maize and barley (Chala, 2018). It is widely cultivated throughout tropical, semi-tropical, arid and semi-arid environments in over 120 countries (USDA, 2016). It is mainly grown as a food crop by small-scale farmers in sub-Saharan Africa (FAO, 2016) and Ethiopia is the fifth sorghum producing country in the world next to America, India, Nigeria and Argentina (Africa Harvest, 2010). Although sorghum can be cultivated in areas where cultivation of other food grains are difficult due to severe moisture and nutrient stresses, its production is being constrained due to parasitism by $S$. hermonthica (Rispail et al., 2007; Hayelom, 2014). This parasitic weed grows on the roots of its host and withdraws photosynthates, minerals and water from the host through a direct connection to the host's xylem via its organ called haustorium.

Infestations by $S$. hermonthica causes severe sorghum yield reduction in which farmers lose sometimes up to 100 percent grain production (Zerihun, 2015). The percentage yield loss of course depends on factors such as the density of the parasite, sorghum variety, soil nutrient status and rainfall patterns (Atera et al., 2012). The problem caused by $S$. hermonthica infestation is expected to grow worse due to its adaptive ability of parasitizing new crops or varieties and adaptation to new environmental conditions 
(Rodenburg and Bastiaan, 2011). Based on the reports of Hadas (2015), S. hermonthica is mainly disseminated across farms through floods from nearby farms, farm tools, and via winds.

Most plants produce some type of organic compounds (secondary metabolites) that are of no direct use for their growth and development (Peteros, 2010), but serve as defense chemicals against biotic and abiotic stresses (Thilagavathi et al., 2015). Secondary metabolites may be synthesized and stored in different parts of the plant body including leaves, stems, roots, flowers, fruits, etc. (Solomon et al., 2013). Alkaloids, terpenoids and phenolic compounds are the most important classes of secondary metabolites (Edeoga et al., 2005), that may have allelopathic effects on neighboring/recipient plants upon liberation into the environments through different means (Mali and Kandae, 2014). Allelochemicals may negatively affect seed germination, seedling growth and establishment of the recipient plant. They exert their negative impacts by modifying resource consumption capacity; alteration of cell membrane permeability and enzymatic activity; triggering genetic defects and disturbing photosynthesis of the recipient plants (Majeed et al., 2012). The allelopathic effect of one plant on another depends on the type and concentration of the allelochemical released as well as the recipient species (Asadduzzaman et al., 2010).

The parasitic nature of striga on sorghum and its negative impact on growth and grain yield of sorghum had long been established by different researchers. For example, Bebawi and Farha (1981) reported that the parasitic striga weed causes reduction in sorghum grain yield by $65 \%$ when compared with $32 \%$ caused by nonparasitic weeds. Parasitism of sorghum by $S$. hermonthica and reduction of its growth and grain yield due to this parasitic weed had also been reported by Showemimo (2006) as well as by Runo and Kuria (2018). There are many reports on the allelopathic nature of sorghum on weeds too (e.g., Alsaadawi and Dayan, 2009; Hozayn et al., 2011) as well as other crops/plants on sorghum (Hassan et al., 2012). Reports show that chemicals released from a given species upon decomposition may be allelopathic to itself too and inhibit germination and seedling growth of its own (Bonanomi et al., 2005). With this premise, we hypothesized that although $S$. hermonthica is a parasitic weed which depends on its host sorghum, it may also be allelopathic to it and negatively affects its host. This study was, therefore, conducted with the objectives of (i) quantifying the major classes of secondary metabolites from extracts of leaf and flower of S. hermonthica and (ii) evaluating the allelopathic effects of different concentrations of $S$. hermonthica extracts on three varieties of S. bicolor.

\section{Materials and Methods}

\section{Plant Materials}

Striga hermonthica was collected from aggressively infested sorghum field around Haramaya University $\left(9^{\circ} 24^{\prime} 53.13^{\prime \prime} \mathrm{N}\right.$ and $\left.42^{\circ} 01^{\prime} 55.69^{\prime} ' \mathrm{E}\right)$ in East Hararghe Zone of the Oromia Regional state, Ethiopia. Seeds of three sorghum varieties: Muyra-1 (M1), Muyra-2 (M2) and Fendishe $(\mathrm{Fe})$ were obtained from Haramaya University sorghum improvement research center.

\section{Preparation of Plant Extracts}

After authentication at the Herbarium of Haramaya University, intact $S$. hermonthica plant was separated into its leaf and flower parts, washed under running tap water and air dried at room temperature in the laboratory. The dried plant parts were separately powdered using mortar and pestle. The powder $(100 \mathrm{~g})$ was macerated separately in $500 \mathrm{ml}$ of distilled water and shaken for 72 hours on a platform shaker at room temperature. Thereafter, the mixture was filtered using Whatman No. 1 filter paper under suction and the filtrates were evaporated under reduced pressure using a rotary evaporator at $55^{\circ} \mathrm{C}$ to remove the solvent. The dried crude extracts were then stored in labeled sterile conical flask at $5^{\circ} \mathrm{C}$ in the refrigerator until use for bioassay.

\section{Classes \\ Quantification of Major Secondary Metabolite}

Total phenolics, total terpenoids and alkaloids in the dried crude extracts were quantified following standard methods as indicated below.

Determination of Total Phenolics: The total phenolics in dried crude extracts of leaf and flower were determined according to the Folin-Ciocalteu procedure (Singleton and Rossi, 1965). About $40 \mathrm{mg}$ of the dried crude extract was mixed with $5 \mathrm{ml} 80 \%$ acetone, shaken well in a Vortexshaker and centrifuged at $2200 \times g$ for $2 \mathrm{~min}$ at room temperature. The supernatant was transferred to a $10 \mathrm{ml}$ volumetric bottle with a Pasteur pipette. The remaining residue was extracted twice with $2.5 \mathrm{ml} 80 \%$ acetone, shaken well in a Vortex-shaker, centrifuged as before after standing for $5 \mathrm{~min}$ and the supernatants were transferred to the same $10 \mathrm{ml}$ volumetric bottle with a Pasteur pipette. Aliquots $(100 \mu \mathrm{l})$ of supernatant from each sample were added to two $10 \mathrm{ml}$ volumetric bottles and mixed with 1.9 $\mathrm{ml}$ deionized water. Folin-Ciocalteu-phenol reagent $(1 \mathrm{ml})$ was added and the solution was shaken vigorously and mixed with $5 \mathrm{ml}$ sodium carbonate (20\%). After $20 \mathrm{~min}$, the solution was centrifuged at $2200 \times g$ for $2 \mathrm{~min}$ at room temperature. Absorbance at $735 \mathrm{~nm}$ was measured in a spectrophotometer (Shimadzu UV-2401PC) and the results were expressed as tannic acid equivalents.

Total Alkaloid Determination: Total alkaloid was determined following the method of Harborne (1973). The dried crude extract $(3 \mathrm{~g})$ was weighed and added into a 50 $\mathrm{ml}$ Erlenmeyer flask. Then, $20 \mathrm{ml}$ of $10 \%$ acetic acid in ethanol was added into the flask and the solution was covered and allowed to stand for $4 \mathrm{hrs}$. Then after, the solution was filtered and concentrated ammonium hydroxide was added drop wise to the filtrate until the formation of precipitate stops. The whole solution was allowed for the precipitate to settle. The precipitate was then collected, washed with dilute ammonium hydroxide and filtered. The obtained precipitate was dried and weighed. Alkaloid content was calculated as mg per $\mathrm{g}$ of the dried crude extract used.

Total Terpenoid Determination: The dried crude extract ( $2 \mathrm{gm}$ ) was soaked in $50 \mathrm{ml}$ of ethanol for $24 \mathrm{hr}$. The solution was then filtered and the filtrate was extracted with $6 \mathrm{ml}$ of petroleum ether using separating funnel. Then, the ether extract was concentrated to dryness using rotary evaporator at $40^{\circ} \mathrm{C}$. The dried ether extract was then considered as total terpenoid (Malik et al., 2017). 


\section{Allelopathic Bioassay of S. hermonthica Extracts}

For allelopathic bioassay, the dried extracts of leaf and flower were first reconstituted in distilled water to have 5 and $10 \%(\mathrm{w} / \mathrm{v})$ concentrations (Samedani et al., 2013). Prior to germination test, seeds of $S$. bicolor varieties were surface-sterilized for 5 min with $5 \%$ sodium hypochlorite $(\mathrm{NaOCl})$ to avoid fungal invasion, and then rinsed thoroughly with distilled water (Hamidi et al., 2013). Thereafter, seeds (10) of each of the S. bicolor variety were sown in $9 \mathrm{~cm}$ diameter Petri dishes lined with double layer of Whatman no.1 filter paper that received $10 \mathrm{ml}$ of the extracts. Distilled water was applied instead of extracts as a control group for comparison. Petri-dishes were incubated in laboratory for days to complete germination. Each experiment was laid out in completely randomized design (CRD) with three replications. Petri dishes were made to get more or less the same amount of light throughout the incubation period and moved around to avoid position effect. Germination was monitored for 15 days with root and shoot lengths, and seedling shoot and root dry weights measured on the 15th day. Percent germination was calculated using the following formula used by Gairola et al. (2011) as follows.

Percent Germination $=\frac{\text { Number of germinated seeds }}{\text { Total number of seeds }} \times 100$

\section{Data Analysis}

General linear model was used to analyze the main effects and their interactions on dependent variables using SPSS, version 20. Independent T-test was used to analyze the difference between leaf and flower in terms of each major secondary metabolite class. Differences between means were considered statistically significant at $P<0.05$.

\section{Results}

Major Secondary Metabolite Classes of the Leaf and Flower Extracts of Striga hermonthica

In this study; total phenolics, terpenoids and alkaloids were detected both in the leaves and flowers of $S$. hermonthica. The amounts of total phenolics and alkaloids showed no significant $(\mathrm{P}>0.05$, Independent $\mathrm{T}$-test $)$ difference between leaves and flowers, whereas total terpenoid content of the flower was significantly $(\mathrm{P}<0.05$, Independent T-test) higher than that of leaf (Figure 1).

Effects of S. hermonthica Extracts on Germination Percentage of Sorghum bicolor Seeds

Both concentration of aqueous extracts and sorghum varieties as main effects, and their interaction significantly $(\mathrm{P}<0.01)$ affected percent seed germination. Under control treatment, germination of seeds of all varieties was $100 \%$, but significantly reduced at $5 \%(\mathrm{w} / \mathrm{v})$ extract concentration and completely inhibited at $10 \% \quad(\mathrm{w} / \mathrm{v})$ extract concentration (Figure 2). However, percent germination was unaffected by OT (organ type extracted, i.e., leaf vs. flower) $(\mathrm{P}=0.198)$; OT and variety interaction $(\mathrm{P}=0.493)$; $\mathrm{OT}$ and extract concentration $(\mathrm{P}=0.194)$; and $\mathrm{OT}$, variety and extract concentration interaction $(\mathrm{P}=0.583)$.

\section{Effects of S. hermonthica Extracts on Shoot and Root} Lengths

Inhibition of shoot and root lengths of the three sorghum varieties was significantly $(\mathrm{P}<0.01)$ affected by extract concentration, sorghum variety and their interaction (Figure $3 \mathrm{~A}$ and $\mathrm{B}$ ). Shoot and root growth inhibitions increased with increasing extract concentrations with actually complete inhibition at $10 \%(\mathrm{w} / \mathrm{v})$ as seeds fail to germinate at this concentration. However, shoot was unaffected by OT $(\mathrm{P}=0.628)$; interaction of OT and sorghum variety $(\mathrm{P}=0.333)$; OT and extract concentration interaction $(\mathrm{P}=0.904)$; interaction of sorghum variety, OT and extract concentration $(\mathrm{P}=0.563)$. Likewise root length was unaffected by OT $(\mathrm{P}=0.05)$, interaction of OT and sorghum variety $(\mathrm{P}=0.300)$; interaction of sorghum variety, OT and extract concentration $(\mathrm{P}=0.557)$ and $\mathrm{OT}$ and extract concentration interaction $(\mathrm{P}=0.052)$.

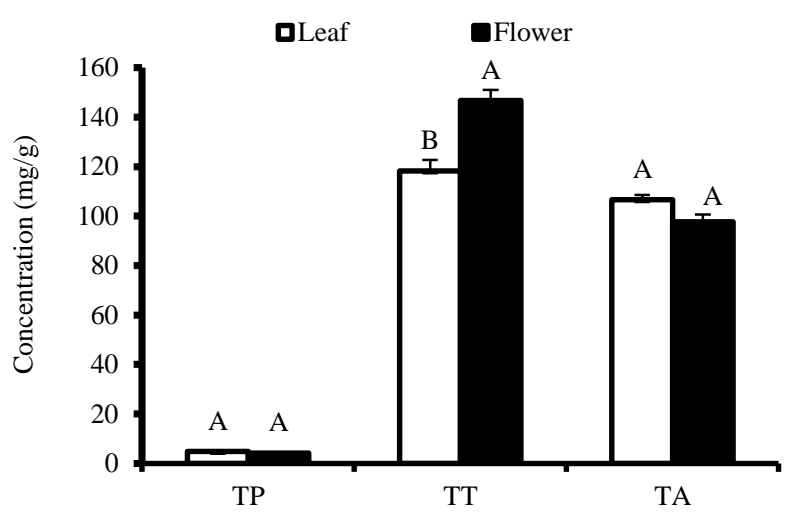

Figure 1. Major Secondary metabolites quantified in Leaf and Flower of $S$. hermonthica.

Values are Mean \pm S.E, $n=3$. Note: $\mathrm{TP}=$ Total Phenolics, $\mathrm{TT}=$ Total Terpenoids and $\mathrm{TA}=$ Total Alkaloids

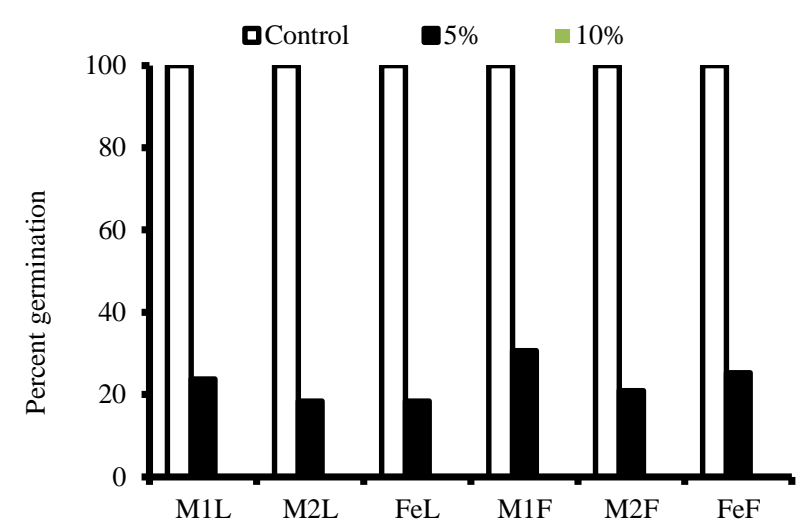

Figure 2. Germination Percentage of Seeds of Three

Varieties of $S$. bicolor treated with different concentrations of Leaf and Flower Aqueous Extracts of $S$. hermonthica.

Values are Mean \pm S.E, $\mathrm{n}=3$. Note: Bar graph for $10 \% \mathrm{w} / \mathrm{v}$ extract concentration did not appear as values are zero. M1L= Muyra-1 treated with leaf extract, $M 2 \mathrm{~L}=$ Muyra-2 treated with leaf extract, $\mathrm{FeL}=$ Fendishe treated with leaf extract, M1F= Muyra-1 treated with flower extract, $\mathrm{M} 2 \mathrm{~F}=$ Muyra-2 treated with flower extract, $\mathrm{FeF}=$ Fendishe treated with flower extract 

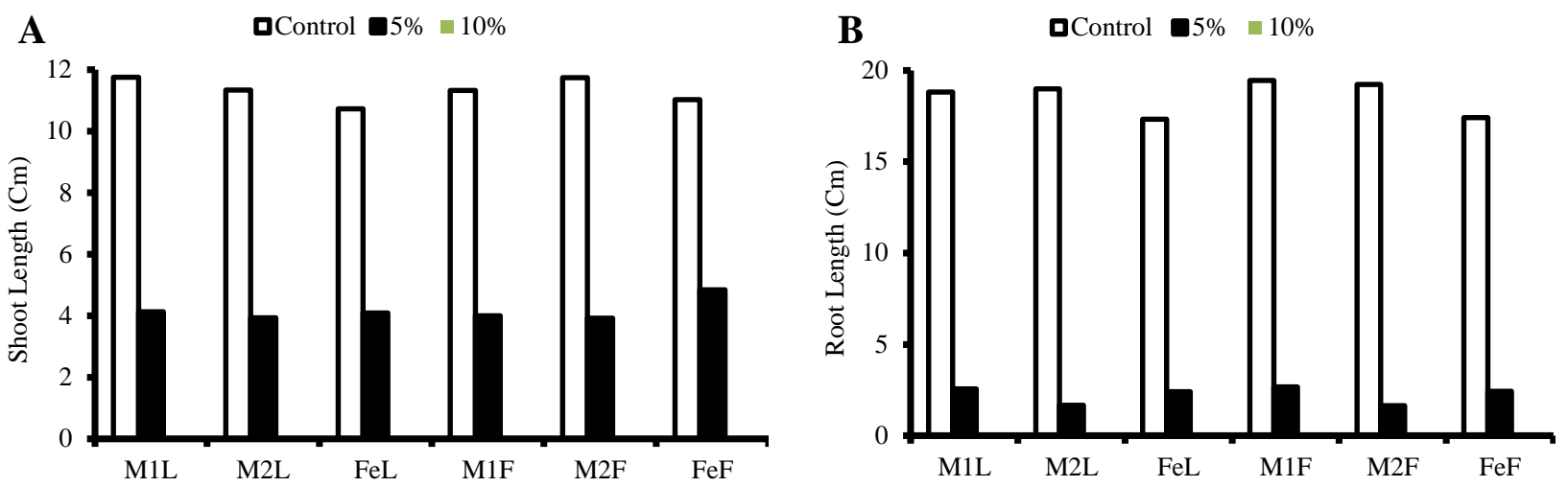

Figure 3. Shoot and Root Lengths of the Three Varieties of S. bicolor treated with different concentrations of Leaf and Flower Aqueous Extracts of S. hermonthica.

Values are Mean \pm S.E, $n=3$. Note: Bar graph for $10 \%$ w/v extract concentration did not appear as values are zero. M1L= Muyra-1 treated with leaf extract, M2L= Muyra-2 treated with leaf extract, FeL= Fendishe treated with leaf extract, M1F= Muyra-1 treated with flower extract, M2F= Muyra-2 treated with flower extract, $\mathrm{FeF}=$ Fendishe treated with flower extract

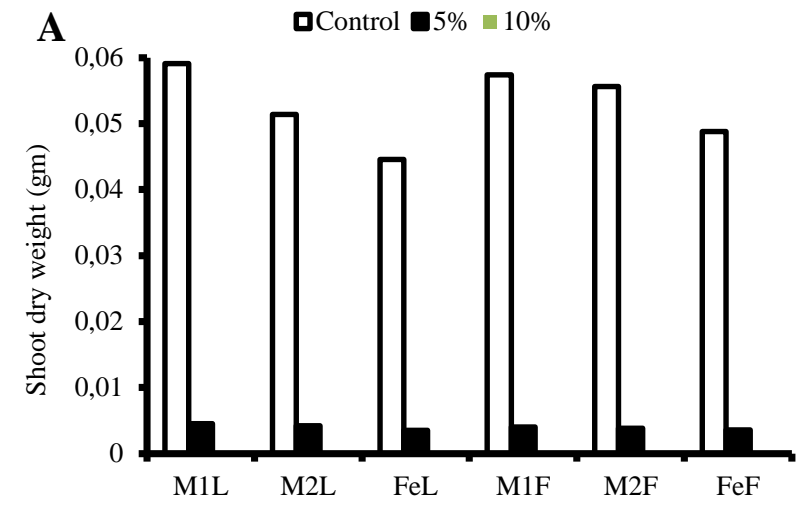

B

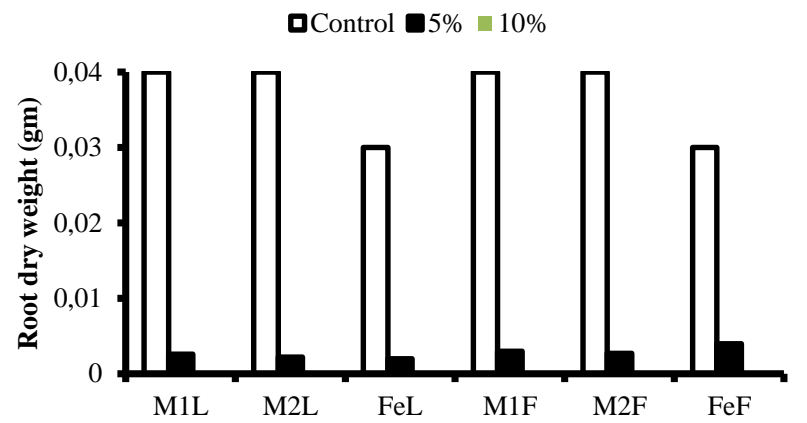

Figure 4. Shoot and Root Dry Weights of the Three Varieties of S. bicolor treated with different concentrations of Leaf and Flower Aqueous Extracts of S. hermonthica.

Values are Mean \pm S.E, $\mathrm{n}=3$. Note: Bar graph for $10 \% \mathrm{w} / \mathrm{v}$ extract concentration did not appear as values are zero. M1L= Muyra-1 treated with leaf extract, M2L= Muyra-2 treated with leaf extract, FeL= Fendishe treated with leaf extract, M1F= Muyra-1 treated with flower extract, M2F= Muyra-2 treated with flower extract, $\mathrm{FeF}=$ Fendishe treated with flower extract

\section{Effects of S. hermonthica Extracts on Shoot and Root Dry Weights}

Shoot dry weight of the three sorghum varieties was significantly $(\mathrm{P}<0.001)$ affected by extract concentration; sorghum variety and their interaction (Fig. 4A). Although OT did not affect shoot dry weight, the interaction of OT and extract concentration $(\mathrm{P}=0.018)$; and interactions of $\mathrm{OT}$, sorghum variety and extract concentration $(\mathrm{P}=0.046)$ significantly affected shoot dry weight (Fig. 4A). Values of shoot dry weight showed highly significant reduction from that of the control treatment at $5 \%(\mathrm{w} / \mathrm{v})$ extract concentration and no measurement was taken at $10 \%(\mathrm{w} / \mathrm{v})$ extract concentration because of complete inhibition of seed germination at this concentration (Fig. 4A). Root dry weight of the three sorghum varieties was also significantly $(\mathrm{P}<0.01)$ affected by extract concentration, but not affected by OT $(\mathrm{P}=0.310)$; variety $(\mathrm{P}=0.388)$; the interactions of OT and variety $(\mathrm{P}=0.309)$; OT and extract concentration $(\mathrm{P}=0.351)$; variety and concentration $(\mathrm{P}=0.423)$; and variety, OT and extract concentration ( $\mathrm{P}=0.332)$ (Fig. 4B). Values of root dry weight showed highly significant reduction from that of the control treatment at $5 \%(\mathrm{w} / \mathrm{v})$ extract concentration and no measurement was taken at $10 \%(\mathrm{w} / \mathrm{v})$ extract concentration because of complete inhibition of seed germination at this concentration (Figure 4B).

\section{Discussion}

\section{Major Secondary Metabolites}

Autoinhibitory effect of plants by chemicals released from same plant species upon decomposition was well documented (Bonanomi et al., 2005; Bonanomi et al., 2007). With this point in mind, we hypothesized that a parasitic plant may also have double negative effect on its host through production of allelochemicals apart from parasitism. The main objective of this study was, therefore, to evaluate $S$. hermonthica extracts for its negative allelopathic effects on its host, sorghum. Prior to allelopathic bioassay, we detected the presence of some allelochemicals in leaves and flowers of S. hermonthica. Here our interest was not to unravel the complete chemical profiles and specific phytotoxic compound(s) (which should be considered in the future), but gross detection of major secondary compound classes including terpenoids, phenolics and alkaloids that often are reported to have allelopathic effects (Macias et al., 1992) in aqueous crude leaf and flower extracts for net allelopathic effect. In our second phase of this study, we evaluated the allelopathic effect of aqueous crude extracts of leaf and flower of $S$. hermonthica on its host, sorghum. Overall, results of this study showed that $S$. hermonthica which parasitizes sorghum also negatively affects its host through allelochemicals produced in its leaves and flowers. 
In this study, results of chemical analysis showed that leaves and flowers of $S$. hermonthica produce phenolics, terpenoids and alkaloids. Okpako and Ajaiyeoba (2004) and Koua et al. (2011), previously detected flavonoids and tannins in aqueous extracts of flowers and other parts of $S$. hermonthica. Koua et al. (2011) showed the presence of trepenes and alkaloids in petroleum ether and ethanol extracts of the entire part of S. hermonthica while Baoua et al. (1980) detected alkaloids in S. hermonthica tissue extracted using water and ethanol. In this study, the amounts of total phenolics and alkaloids showed no significant difference between leaves and flowers, whereas total terpenoid content of the flower was significantly higher than that of leaf. Ibrahim et al. (2010) and Jiang et al. (2016) reported that floral parts of the plants they investigated produce terpenoids more than leaves. Hansen and Seufert (1999) also reported 7.8-fold higher total emissions of terpenoids from Citrus sinensis (L.) branches with flowers than from branches without flowers. Total terpenoids of this study may be array of different components that are produced to give flowers their characteristic scent that may help them attract pollinators (Flamini et al., 2003). Therefore, higher amount of terpenoids in flowers than leaves may be attributed to additional roles they have in flowers. These three classes of secondary metabolites have been reported to have defensive roles against abiotic and biotic stresses (Egigu et al., 2011) and also known for their allelopathic effect (Macias et al., 1992; Mali and Kandae, 2014) upon liberation into the soil mainly through decomposition of the donor plant tissues. Thus, detection of these classes of secondary compounds suggests the potential of $S$. hermonthica to be allelopathic to recipient plants including its host, S. bicolor, and the same was confirmed from allelopathic bioassay.

\section{Allelopathic Bioassay}

From allelopathic bioassay, we noticed $100 \%$ seed germination of the three tested sorghum varieties under control treatment. However, percent germination was significantly reduced at $5 \%(\mathrm{w} / \mathrm{v})$ extract concentration and completely inhibited at $10 \%$ (w/v) extract concentration. Given the same extract concentration, percent germination did not vary with verities tested and organ type extracted. Seed germination may be hindered due to inhibition of water uptake (Tawaha and Turk, 2003). It may also be inhibited due to hampered resource mobilization by allelochemicals during early stages of seed germination (Gniazowska and Bogtek, 2005). It is also possible that allelochemicals such as some phenolic compounds impair the synthesis and/or activity of gibberellic acid (Einhellig, 1996) which regulates the production of amylase (Chandler et al., 1984) so that seed germination is negatively affected.

Growth of shoot and root including their lengths and dry weights of the three tested sorghum varieties was highly reduced by aqueous extracts of both leaf and flower of $S$. hermonthica and growth reduction was more pronounced with increasing extract concentration. Previously, Einhellig (1996) reported that allelochemicals decrease elongation, expansion and division of cells which are growth prerequisites. The inhibition of shoot and root lengths by $S$. hermonthica extracts also suggests the occurrence of some allelochemicals that interfere with important metabolic activities that promote cell division and elongation. Sasikumar et al. (2002) reported the inhibitory effects of phenolic compounds on phosphorylation pathway, $\mathrm{Mg}$ activation and ATPase activity. They also mentioned that allelochemicals might decrease synthesis of total carbohydrates, proteins and nucleic acids (DNA and RNA) hence negatively affect growth. Given the same concentration, OT had no differential effect on the same variety in terms of these parameters. Although leaf extract had no varying effect on the three varieties, flower extract exhibited differential effect on shoot lengths of the three varieties whereby variety Fendishe (Fe) was less affected than Muyra-1 (M1) and Muyra-2 (M2), suggesting that some unique chemicals must have been released from flower extract to more suppress shoot length of M1 and M2 than Fe. In terms of root length also, variety $\mathrm{Fe}$ was found to be superior than the others. Sensitivity of crops to allelochemicals varies with species and genotypes within species (Asghari and Tewari, 2007; Baličević et al., 2014). This finding is also in agreement with Hassan et al. (2012) who reported that extract of botanicals have differential negative impacts on shoot dry weight of different sorghum varieties. In contrast to shoot, root length was more suppressed than that of shoot with at least 1.5 -fold reduction from that of shoot length at $5 \%(\mathrm{w} / \mathrm{v})$ extract concentration. This may be attributed to the impairment of endogenous plant growth hormones synthesis and/or activity in the root by allelochemicals.

In conclusion, inhibitory effects of allelochemical at a germination and early seedling growth stage may predispose crops to other abiotic and biotic stresses, hence reduces their productivity (Dekker and Maggitt, 1983). So far, research have shown significant reduction in sorghum yield due to infestation by parasitic $S$. hermonthica for which the mechanism of attack was simply attributed to its parasitism. However, this study for the first time revealed that $S$. hermonthica has dual negative effect on sorghum through production of allelochemicals apart from parasitizing its host.

\section{Acknowledgements}

This research was supported by the Ethiopian Ministry of Education. The authors would like to thank the Haramaya University, School of Biological Sciences and Biotechnology, and School of Plant Sciences for laboratory facilities.

\section{References}

Africa Harvest. 2010. Importance of sorghum with respect to Africa. Available at: http://biosorghum.org /importance_sorhum_africa.php. (Accessed on July 5, 2017).

Alsaadawi IS, Dayan FE. 2009. Potentials and prospects of sorghum allelopathy in agroecosystems. Allelopathy J., 24: 255-270.

Asadduzzaman MD, Mahbub IM, Shamima S. 2010. Allelopathy and allelochemicals in rice weed management. Bangladesh Research Publications Journal., 4: 1-14.

Asghari J, Tewari JP. 2007. Allelopathic Potentials of Eight Barley Cultivars on Brassica juncea (L.) Czern. and Setaria viridis (L.) Beauv. J Agr Sci Tech., 9: 165-176.

Atera EA, Azuma T, Ishii T. 2012. Farmers perspective on the biotic constraint of Striga hermonthica and its control in Western Kenya. Weed Biol. Manag., 12: 53-62. 
Baličević R, Ravlić M, Knežević M, Serezlija I. 2014 Allelopathic effect of field bindweed (Convolvulus arvensis L.) water extracts on germination and initial growth of maize. Anim Plant Sci., 24: 1844-1848.

Baoua M, Bessiere JM, Pucci B, Rigaud JP. 1980. Alkaloids from Striga hermonthica. Phytochemistry., 19: 718.

Bebawi F, Farah AF. 1981. Effects of Parasitic and Non-Parasitic Weeds on Sorghum. Exp. Agric., 17: 415 - 418

Bonanomi G, Del Sorbo G, Mazzoleni S, Scala F. 2007. Autotoxicity of decaying tomato residues affects susceptibility of tomato to fusarium wilt. J Plant Pathol., 89: 219-226.

Bonanomi G, Legg C, Mazzoleni S. 2005. Autoinhibition of germination and seedling establishment by leachate of Calluna vulgaris leaves and litter. Community Ecol.,6:203-208.

Chala CB. 2018. Sorghum [Sorghum bicolor (L.)] Breeding in Ethiopia: Review. Journal of Biology, Agriculture and Healthcare., 8: 2224-3208.

Chandler PM, Zucar JA, Jacobson JV, Higgins TJV, Inglis AS. 1984. The effect of gibberellic acid and abscisic acid on aamylase mRNA levels in barley aleurone layers studies amylase cDNA clone. Plant Mol. Biol., 3: 407-408.

Dekker J, Maggitt WF. 1983. Interference between velvet leaf (Abutilon theophrasti Medic.) and soybean (Glycine max (L) Merr.) I. Growth. Weed Res., 23: 91-101.

Edeoga HO, Okwu DE, Mbaebie BO. 2005. Phytochemical constituents of some Nigerian medicinal plants. Afr. J Biot., 4: 685-688.

Egigu MC, Ibrahim MA, Yahya A, Holopainen JK. 2011. Cordeauxia edulis and Rhododendron tomentosum extracts disturb orientation and feeding behavior of Hylobius abietis and Phyllodecta laticollis.Entomol Exp Appl., 138: 162 - 174.

Einhellig FA. 1996. Mechanism of action of allelochemicals in allelopathy. Agron. J., 88: 886-893.

FAO. 2016. FAOSTAT, Food and Agriculture Organization of the United Nations). [Online] Available at: http://faostat3.fao.org /browse/Q/QC/E (Accessed on June 18, 2018).

Flamini G, Cioni PL, Morelli I, Ceccarini L, Andolfi L, Macchia M. 2003.Composition of the essential oil of Medicago marina L. from the coastal dunes of Tuscany, Italy. Flavour Fragr. J., 18: 460-462

Gairola KC, Nautiyal AR, Dwivedi AK. 2011. Effect of temperatures and germination media on seed germination of Jatropha curcas L. Adv. Biomed. Res., 2: 66-71.

Gniazowska A, Bogatek R. 2005. Allelopathic interactions between plants. Multi-site action of allelochemicals. Acta Physiol. Plantarum., 27: 395-407.

Hadas B. 2015. Distribution, Abundance and Socio-Economic Impacts of Parthenium (Parthenium hysterophorus) in Southern Zone of Tigray, Ethiopia, Journal of Poverty, Investment and Development., 19: 22-29.

Hamidi R, Pirasteh-Anosheh H, Izadi M. 2013. Effect of seed halo-priming compared with hydro-priming on wheat germination and growth. Int J Plant Prod., 4: 1611-1615.

Hansen U, Seufert G. 1999. Terpenoid Emission from Citrus sinensis (L.) OSBECK under Drought Stress. Phys. Chem. Earth (B)., 42: 681-687.

Harborne JB. 1973. Phytochemical Methods: A Guide to Modern Techniques of Plant Analysis. Chapman and Hall: Ltd. London. UK.

Hassan MM, Daffalla HM, Yagoub SO, Osman MG, Abdel Gani ME, Babiker EA. 2012. Allelopathic effects of some botanical extracts on germination and seedling growth of Sorghum bicolor L. Journal of Agricultural Technology., 8: 1423-1469.

Hayelom B. 2014. Advanced research on Striga hermonthica control: A review, Afr. J. Plant Sci.,8: 492 -506.

Hozayn M, Lateef EMA, Sharar FF, Monem AAA. 2011. Potential uses of sorghum and sunflower residues for weed control and to improve lentil yields. Allelopathy J., 27: 15-22.
Ibrahim MA, Egigu MC, Kasurinen A, Yahya A, Holopainen JK. 2010. Diversity of volatile organic compound emissions from flowering and vegetative branches of Yeheb, Cordeauxia edulis (Caesalpiniaceae), a threatened evergreen desertshrub.Flavour Fragr. J., 25: 83 - 92.

Jiang Y, Ye J, Li S, Niinemets U. 2016. Regulation of floral terpenoid emission and biosynthesis in Sweet Basil (Ocimum basilicum). J Plant Growth Regul., 35: 921-935.

Koua FHM, Babiker HAA, Halfawi A, Ibrahim RO, Abbas FM, Elgaali EI, Khalafallah MM. 2011. Phytochemical and biological study of Striga hermonthica (Del.) Benth Callus and Intact Plant. Res. Pharma. Biotechnol., 3: 85-92.

Macias FA, Galindo JCG, Massanot GM. 1992. Potential allelopathic activity of several sesquterpene lactone models, Phytochemistry, 31: 1969-1777.

Majeed A, Chaudhry Z, Muhammad Z. 2012. Allelopathic assessment of fresh aqueuous extracts of Chenopodium album L. for growth and yield of wheat (Triticum aestivum L.). Pak J Bot., 44: 165-167.

Mali AA, Kanade MB. 2014. Allelopathic effect of two common weeds on seed germination, roots-shoot length, biomass and protein content of Jowar. Ann. Biol. Res., 5: 89-92.

Malik SK, Ahmad M, Khan F. 2017. Qualitative and quantitative estimation of terpenoid contents in some important plants of Punjab, Pakistan. Pak. J. Sci., 69: 150-154.

Okpako LC, Ajaiyeoba EO. 2004. In vitro and in vivo antimalarial studies of Striga hermonthica and Tapinanthus sessilifolius extracts. Afr. J. Med. Sci., 33: 73-75.

Peteros NP. 2010. Antioxidant and cytotoxic activities and phytochemical screening of four Phillppine medicinal plants. J. Med. Plants Res., 4: 407-414.

Rispail N, Dita MA, Gonzlez-Verdejo C, Prezde-Luque A, Castillejo MA, Prats E, Rubiales D. 2007. Plant resistance to parasitic plants: molecular approaches to an old foe. New Phytol., 173: 703-712.

Rodenburg J, Bastiaans L. 2011. Host-plant defense against Striga hermonthica: reconsidering the role of tolerance. Weed Res., 51: 438-441.

Runo S, Kuria, E. 2018. Habits of a Highly Successful Cereal Killer, Striga. PLoS Pathogens, 14: e1006731.

Samedani B, Juraimi AS, Rafii MY, Anuar AR, Sheikh-Awadz SA, Anwar MP. 2013. Allelopathic effects of litter Axonopus compressus against two weedy species and its persistence in soil. Sci. World J., 695-404.

Sasikumar K, Vijayalakshmi C, Parthiban KT. 2002. Alleopathic effects of Eucalyptus on blackgram (Phaseolus mungo L.). Allelopathy J., 9: 205-214.

Showemimo FA. 2006. Effect of Striga hermonthica on yield and yield components of sorghum in Northern Guinea savanna of Nigeria. J. Plant Sci., 1: 67-71.

Singleton VL, Rossi JA. 1965. Colorimetry of Total Phenolics with Phosphomolybdic-Phosphotungstic Acid Reagents. Am J Enol Vitic., 16: 144-158.

Solomon CU, Arukwe UI, Onuoha I. 2013. Preliminary phytochemical screening of different solvent extracts of stems bark and roots of Dennetia tripetala. Asian J PlantSci Res., 3: 10-13.

Tawaha AM, Turk MA. 2003. Allelopathic effects of black mustard (Brassica nigra) on germination and growth of wild barley ( Hordeum spontaneum). J. Agron. Crop Sci., 189: 298-303.

Thilagavathi T, Arvindganth R, Vidhya D, Dhivya R. 2015. Preliminary Phytochemical screening of different solvent mediated medicinal plant extracts evaluated. Int. Res. J. Pharm., 6: 246-248.

USDA (United States of Department of Agriculture). 2016. World Sorghum Production 2015/2016. Available at: https://www.worldsorghumproduction.com/. (Accessed on June 1, 2018).

Zerihun S. 2015. Effect of nitrogen fertilizer on Striga hermonthica infestation, yield and yield related traits on sorghum [Sorghum bicolor (L.) Moench] varieties at Kile, Eastern Ethiopia. M.Sc. Thesis, Haramaya University, Ethiopia. 